NBER WORKING PAPER SERIES

\title{
THE TRANSFORMATION OF HUNGER: THE DEMAND FOR CALORIES PAST AND PRESENT
}

\author{
Trevon D. Logan \\ Working Paper 11754 \\ http://www.nber.org/papers/w11754 \\ NATIONAL BUREAU OF ECONOMIC RESEARCH \\ 1050 Massachusetts Avenue \\ Cambridge, MA 02138 \\ November 2005
}

I thank Raj Arunachalam, Andrea A. Cann, Dora L. Costa, William A. Darity, Jr., J. Bradford DeLong, Ronald D. Lee, Thomas Logan, Sr., Edward A. Miguel, Muna S. Meky, Martha L. Olney, James L. Powell, Steven Raphael, Christina D. Romer, Kenneth W. Wachter, and numerous seminar participants for extremely helpful discussions and comments on various aspects of this work. Dora L. Costa, Michael R. Haines, and Richard H. Steckel alerted me to data sources. Portions of this research were supported by the National Institute of Child Health and Human Development. All views expressed herein and errors, both of omission and commission, are my own. The views expressed herein are those of the author(s) and do not necessarily reflect the views of the National Bureau of Economic Research.

(C2005 by Trevon D. Logan. All rights reserved. Short sections of text, not to exceed two paragraphs, may be quoted without explicit permission provided that full credit, including (C) notice, is given to the source. 
The Transformation of Hunger: The Demand for Calories Past and Present

Trevon D. Logan

NBER Working Paper No. 11754

November 2005

JEL No. D12, I12, I31, J10, N31

\begin{abstract}
According to conventional income measures, nineteenth century American and British industrial workers were two to four times as wealthy as poor people in developing countries today. Surprisingly, however, today's poor are less hungry than yesterday's wealthy industrial workers. I estimate the demand for calories of American and British industrial workers using the 1888 Cost of Living Survey and find that the estimated calorie elasticities for both American and British households are greater than calorie elasticity estimates for households in present day developing countries. The results are robust to measurement error, unreported food consumption, and indirect estimation bias. This finding implies substantial nutritional improvements among the poor in the twentieth century. Using the Engel curve implied by the historical calorie elasticities, I derive new income estimates for developing countries which yield income estimates that are six to ten times greater than those derived using purchasing power parity or GDP deflators.

Trevon D. Logan

The Ohio State University

410 Arps Hall

1945 North High Street

Columbus, $\mathrm{OH} 43210$

and NBER

logan.155@osu.edu
\end{abstract}




\section{Introduction}

The goal of this paper is to bring together the work of economic historians, who have produced a vast literature on health, nutrition, and economic growth, and development economists, who have also been concerned with such matters but tend to concentrate on different measures. Hunger continues to plague many developing nations and the poorest segments of developed nations. If the past is prologue, developing nations may be well served by studies that explore the dimensions of hunger and malnutrition in the past. In particular, this paper explores how the relationship between income and nutrition for industrial workers in the United States and Great Britain in the late nineteenth century compares to the situation in today’s developing countries.

To make comparisons of living standards across time one must adopt a metric that is both consistent over time and that quantifies a meaningful dimension of human life whose relationship to living standards is straightforward and easily understood. Given the long human struggle with subsistence, calorie elasticities are an excellent way to quantify the demand for food and to do so in a unit free manner. While looking at the average number of calories per person or the share of the budget devoted to food over time may be suggestive, such analysis must be qualified by changes in human physiology, dietary tastes, food quality, and prices over time and space. Indeed, knowing only the average number of calories per person or the fraction of the budget devoted to food in two different populations would not establish which population was hungrier without additional information or assumptions. ${ }^{1}$ Elasticities, however, quantify the

\footnotetext{
${ }^{1}$ Many of the problems that may be present in the level of calories will not be present in demand elasticities, which are more robust than calorie averages. For example, the lack of information about the home production of calories for historical households is shown to have very little effect on the historical elasticities presented here, but such an omission would lead to biased estimates of average caloric intake. Also, our estimates of calories per capita for historical populations are rarely based on microeconomic evidence- they are usually based on nutritional balance sheets, and as such are not directly comparable to calorie per head estimates from developing countries.
} 
demand for goods in the same way across both time and space, and underlying their use is textbook microeconomic theory. While food elasticities will not be comparable if people purchase more and more expensive food as their incomes grow, calorie elasticities are an intuitive and straightforward way to estimate hunger.

I compare late nineteenth century estimates of income and expenditure elasticities of calories for industrial workers in the United States and Great Britain to those from developing countries today. These calorie elasticities estimate the responsiveness of calorie demand given a change in income. The calorie elasticities discussed here measure the percentage increase of calories in the diet given a one percent increase in income or expenditure. While calorie elasticity estimation is standard in development economics, the size of the elasticity in historical populations is unknown, and we therefore know very little about how calorie demand has changed over time.

Using the microeconometric techniques of contemporary development economics to analyze living standards in the past is important in two ways. First, this methodology allows us to look at living standards today and in the past in the same way. This gives us a common measure for living standards and eliminates the need to heavily qualify our comparisons of the past and present. Secondly, this methodology allows us to ask and answer the question of how living standards have changed over time, and this is one of the fundamental questions in economics. Calorie elasticities can only be estimated with detailed microeconomic data, and not all historical household survey data is appropriate for this purpose. The historical data used in this paper, the 1888 Cost of Living Survey, is one of the few historical household surveys that allow us to derive precise estimates of historical nutrition, which are necessary to estimate calorie elasticities. 
I find that the estimates of calorie elasticities for both British and American households in the late nineteenth century are greater than contemporary calorie elasticity estimates in the developing world today. When I compare my estimates with calorie elasticity estimates from developing countries I find that my estimates are outliers—-the historical elasticity estimates are at the highest end of calorie elasticity estimates. More concretely, the hypothesis that the historical expenditure elasticity of calories estimates are equal to or less than Subramanian and Deaton’s (1996) estimates for rural India in 1983 is strongly rejected in every econometric specification. When one considers that American and British industrial workers in the late nineteenth century, using conventional income measures, are at least twice as wealthy as a household in rural India in 1983, this result is surprising. ${ }^{2}$ This finding implies an extraordinary improvement in nutritional well-being among the poor in the last century. I also discover that the validity of the comparison across time is strengthened by historical narrative evidence. In particular, the findings here are robust to estimation bias, the failure to capture home produced calories in the 1888 Cost of Living Survey and measurement error.

Using the Engel curve implied by the calorie elasticities for both American and British households, I construct an expenditure elasticity of calories-aggregate income relationship. Using the calorie elasticity estimates for developing countries, I derive new aggregate income estimates for developing countries based upon the Engel curve. Traditional income estimates imply that those in developing countries today are many times poorer than American and British workers in the late nineteenth century. Unlike the aggregate income estimates derived from GDP deflators or purchasing power parity (PPP), the Engel based estimates imply that those in developing countries are wealthier than American or British households in the late nineteenth century. In particular, the Engel-based income estimates are six to ten times greater than

\footnotetext{
${ }^{2}$ For more on historical income measures see Maddison (1995).
} 
traditional income estimates. While the Engel curve may or may not be the optimal way to derive estimates of income, the fact that the income estimates are many times greater than the traditional estimates shows another dimension upon which our traditional income measures may be flawed.

In total, these facts lead to two related conclusions. The first is that the press of hunger has transformed dramatically over time and in a way not captured by our income estimates. These new income estimates also imply that economic growth may be understated. Either those in the past were much poorer than previously thought or those from developing countries are wealthier than our income estimates predict. In both cases the conclusion is the same-living standards have increased dramatically over time, and our current estimates of economic growth are too low.

\section{Data and Summary Dietary Measures}

The historical calorie elasticities presented in this paper come from a unique and rich household survey from the late nineteenth century. The survey, called the "Cost of Living of Industrial Workers in the United States and Europe 1888-1890” (henceforth 1888CEX), was conducted by the United States Department of Labor to asses the living standards of American and European industrial workers in the late nineteenth century. The 1888CEX contains a sample of 8,544 families working in industrial sectors in both Western Europe and the United States. The majority of the households in the survey, 6,809, are from the United States. The European sub-sample comes from Germany, Switzerland, Belgium, Great Britain, and France, although the majority of the European households, 1,024, come from Great Britain. Since the survey was designed to investigate the living standards of industrial households, the geographic distribution 
of households in the United States is not even, but both the American and British samples appear to be broadly representative of industrial households at the time. ${ }^{3}$

The survey contains detailed annual expenditure information for both food and non-food items and annual income information for all members of the household (father, mother, and children). In addition, demographic information on the household's age and sex composition, as well as a detailed recording of the household head's occupation, is included in the survey. Calorie conversions were created in conjunction with the Aldrich Report on retail prices in a methodology described by Logan (2005). Throughout the paper, per capita calories (PCC) are defined as the total annual quantity of calories available to a household divided by household size. Income and expenditure are also standardized by household size, and per capita income (PCI) and per capita expenditure (PCE) are calculated by taking total annual income and expenditure and dividing them by the total number of people in the household, respectively.

Before turning to calorie elasticity estimates, it may be useful to present other measures of nutrition that can be derived from the survey. In particular, average calories per head, the percent of the budget devoted to food, and the average price of calories as a percent of a day's wage are all useful ways of measuring nutritional well-being. While these measures do not have the straightforward economic interpretation of calorie elasticities and may not be strongly related to hunger per se, these measures should be brought into the analysis as a motivation for using calorie elasticities as the economic quantification of hunger. To foreshadow the case study presented in the next section, I will compare the historical summary measures with those for India in 1983 as given by Subramanian and Deaton (1996).

\footnotetext{
${ }^{3}$ See Haines (1979), Lees (1979), and Modell (1978) for more on the types of households sampled, sampling methodology, and the representativeness of the 1888CEX. For more on the use of household surveys in economics see Stigler (1954) and Deaton (1997).
} 
The most obvious summary measure of nutrition is the average number of calories per person. Table 1 shows the average calories per head for the American and British samples of the 1888CEX as well as those for India in 1983. As the table shows, those in the late nineteenth century had far fewer calories per head than those in India. The Indian households in 1983 had 40\% more calories than British industrial households, and 20\% more calories than American industrial households. By this measure, it would appear that those in the past were nutritionally worse off, and this directly contradicts the conclusions one would draw from the income comparisons. At a minimum, the calorie levels suggest that we look deeper at the nutritional well-being of these households.

But can we make inferences about hunger based on calories per head? Yes and no. While it is easy to conjecture that more calories are better, it is harder to say who is hungrier. In order to make the case that one group was hungrier than another we would need answers to the following questions: What are the calorie requirements of the two groups? Are there differences in calorie wastage between the two groups? Would technology differences effect the preparation of food? How is food, in general, distributed in this culture, and what manipulations to the data must be performed in order to capture those features of food distribution? Since so much additional information is needed, the issue of hunger, or demand for nutrition, cannot be known from average calories alone. While the implication of the calorie levels reported here suggest that those in developing countries are doing much better nutritionally than nineteenth century industrial workers, we need more information to make such a conjecture a conclusion.

The share of the budget devoted to food has been a measure of well being since Engel first noted the proposition that wealthier families devoted a smaller share of their budget to food than poorer families. Since that time it has been regarded as a measure of well-being. Table 1 
lists the fraction of the budget devoted to food for the American and British samples of the 1888CEX as well as those for India in 1983. As the table shows, American and British families in the late nineteenth century devoted at best $50 \%$ of expenditure to food, while those in India devoted more than $60 \%$ of expenditure to food. The budget shares suggest that those in India are slightly worse off than industrial families in the United States and Great Britain in the late nineteenth century. From this measure of nutritional well-being we would reach the opposite conclusion from that obtained with calorie levels.

The open question is whether the share of the budget devoted to food is the appropriate quantification of hunger. There are several problems with budget shares as the measure of hunger. Budget shares take no account of the trade-offs between home production and direct purchases of food, differences in calorie price, or differences in the price of other necessities such as heating fuel and shelter. Budget shares also tell us nothing about diet quality, and it could be true that equal fractions of the same budget could yield very different bundles of food with highly dissimilar quality and subsequently large differences in nutritional well-being. As such, it is unclear how we should interpret differences in the budget share devoted to food, particularly over time.

The third measure of nutrition would be the price of calories. Economists such as Mirrlees (1975) and Stiglitz (1976) have described the situation in which people are so wasted that they cannot work, and this leads to very low wages and continued malnourishment. In this way, a person is trapped in a malnourishment and poverty feedback loop—poor nutrition produces low income, and this low income produces further poor nutrition. There is little evidence that these sorts of poverty traps exist in present day populations. Fogel (1994b) has asserted that such traps did exist well into the eighteenth century, although he too concedes that 
these sorts of poverty traps, where nutrition feeds back to wages, were non-existent in western populations after the middle of the nineteenth century.

If these sorts of poverty traps did exist the demand equations estimated later in this paper and by others would be endogenous, so it is useful to analyze the price of calories before estimating the elasticity. Endogeneity would only be a problem, however, if one could produce evidence that a day's worth of calories (both calories needed for sustenance and for a day's worth of labor) were far out of reach of the general population. As Table 1 shows, a day's worth of calories (using 2,300 calories as a lower bound) cost around ten percent of a typical day's wage among industrial workers in the United States, and around thirteen percent of an industrial worker's daily wage in Great Britain. Subramanian and Deaton (1996) find that a day's worth of calories, namely 2,600 calories a day-more than needed for sustenance and a day of hard labor, cost less than five percent of a typical day's wage in Maharastra, India in 1983. By this measure those in India are better off than the industrial workers in the late nineteenth century. Even when looking by industry, which helps control for calorie price and income differentials, the variation in the percentage is slight, and even households in the highest paid industries would have to devote a larger fraction of their daily wage to obtain 2,600 calories than those in India today. While these percentages of the daily wage imply that it is doubtful that nutrition fed back to income in the late nineteenth century, they are still much greater than the low values calculated for India.

It is surprising that calories cost less than a $20^{\text {th }}$ of a day’s wage in rural India in 1983 and more than a $10^{\text {th }}$ of a day's wage in both the United States and Great Britain. Certainly one conclusion that could be drawn from such a fact is that the price of calories has declined dramatically in the last century. The fraction of the nineteenth century industrial workers wage, 
in today's income, is many times larger than the value of the low wages earned in India, which could be used as a rough way of measuring the decline in calorie prices over time.

These summary measures are informative, and yet they do not all point in the same direction. While average calories and calorie prices tell us that those in the past were worse off, the budget share tells us that both groups were nearly equally well off. While these results by themselves conflict with inferences based on income estimates, it is not clear if any of these measures capture living standards and quality of life, at least on their own. Additionally, these measures do not survive time and space transformations well. A more economic approach, where we quantify the demand for nutrition, would allow us to quantify hunger in such a way that we could compare demand over time and space. The most intuitive candidate is the calorie elasticity, a straightforward quantification of nutritional demand that has a direct economic interpretation.

Given that calories are necessities, we should expect them to be income and expenditure inelastic. Furthermore, we would generally say that households with large calorie elasticities are hungrier than households with small calorie elasticities. This follows from our intuition that if one is hungry they will devote a large share of their marginal income to securing more calories. Following basic principles, demand for calories, $x$, can be thought of as a function of prices and income, $x_{i}\left(p_{1}, \ldots, p_{n}, I\right)$ or prices and expenditure, $x_{i}\left(p_{1}, \ldots, p_{n}, E\right)$. The income elasticity of calories is defined to be

$$
\eta_{i}=\frac{\partial \ln x_{i}\left(p_{1}, \ldots, p_{n}, I\right)}{\partial \ln I}
$$

The expenditure elasticity is defined analogously. Since elasticities are unit-free measures of demand responsiveness, they can be compared over time and space without the qualifiers, caveats, and conjectures needed when using the other measures mentioned above. Additionally, 
calorie elasticities reflect demand for nutrition, not a predescribed measure of nutritional adequacy. As such, calorie elasticities allow us to compare demand for nutrition and infer which group is hungrier than another.

In the following sections I compare my historical estimates of the calorie elasticity to those from developing countries today. While there is no general agreement on the size of the calorie elasticity in developing countries an upper bound has been established in the literature. As will be shown, the historical calorie elasticities presented here are above the upper bound seen for developing countries today. To make the comparison concrete, I first compare the historical estimates to the range advanced by Subramanian and Deaton (1996), who find that the expenditure elasticity of calories is between .3 and .5 for families in rural Indian villages in 1983. I compare my results to their estimates as a case study for three reasons. First, my methodology is similar to theirs, and it is important to have similar methodologies if the results are to be comparable. ${ }^{4}$ Secondly, Subramanian and Deaton’s work is concerned with a rural population in the developing world, and as such it serves as an example of the sorts of space and time comparisons one may do when using caloric elasticity estimates. Third, their work is concerned with the plausible range of calorie elasticities for developing countries, and their findings have been influential for development economists concerned with crafting economic policies that will be effective in eliminating hunger. I then compare the historical elasticity estimates with a broad sampling of calorie elasticity estimates from the developing world, and also explore how the conclusions drawn from the calorie elasticity comparisons are similar to and different from the conclusions drawn from comparing other measures of well-being. 


\section{Comparing Calorie Elasticities - A Case Study}

\section{A. Calorie Elasticity Estimates}

Following convention, I estimate the elasticity with the log linear equation

$$
\ln \left(x_{i}\right)=\alpha+\beta \ln \left(I_{i}\right)+\Gamma Z_{i}+\varepsilon_{i}
$$

where $\beta$ is the elasticity and $\mathrm{Z}$ a vector of controls. The log linear functions presented here were estimated using ordinary least squares (OLS). Since taking the logs of both income and calories produces an approximate joint normality, OLS is indeed appropriate for estimating the elasticity. The OLS regression estimates presented here are taken as summary measures of each respective population's demand for calories.

Table 2 shows the OLS regressions of the calorie elasticities for American and British households in the late nineteenth century. As the table shows, the American calorie elasticities are ten to forty percent lower than the corresponding British calorie elasticities. These differences suggest a large gap in the nutritional well-being of the British and American industrial classes in the late nineteenth century in favor of American households. When one considers Lees’ (1979) description of the British households in the 1888CEX these results may well understate that differential. Narrative evidence confirms British industrial families were more malnourished than American industrial households in the late nineteenth century, so we would expect the British calorie elasticities to be greater than the American calorie elasticities. ${ }^{5}$ Given their congruence with the historical record, a comparison of these historical elasticities with those from contemporary countries seems appropriate.

\footnotetext{
${ }^{4}$ Our sample sizes are also similar, which enhances the comparison.

${ }^{5}$ See Shergold (1982) for more on comparative living standards in the late nineteenth century, and Logan (2005) for more on the calories elasticity differential between the US and Great Britain.
} 
Subramainian and Deaton (1996) estimate the expenditure elasticity of calories in rural India. Their data come from the thirty-eighth round of the National Sample Survey (NSS) in 1983. They have a total sample of 5,630 households, 10 from each of 563 villages. Using both parametric and non-parametric techniques, they conclude that "the range of estimates that we have established for the expenditure elasticity of calories, from .3 to .5 , is the right one for this part of rural India,” (p. 161).

Before turning to features of the case study it is important to note that comparing like calorie elasticity estimates is best, and this will only be true if the measures of calorie availability are similar. While constructing the NSS data to be similar to the 1888CEX and then estimating the caloric elasticities would be an attractive research strategy, it would not be as informative as the results presented below. ${ }^{6}$ Constructing the NSS as if it were the 1888CEX would create biased caloric availability measures in the Indian data. It is well known that in Indian villages poor families consume many meals outside of the home and wealthy families serve many meals in their homes that are not consumed by household members. ${ }^{7}$ With this being true, simply taking household measures of calories would systematically understate the calories available to poor households and overstate the calories available to wealthy households in the NSS. For this reason, Subramanian and Deaton construct their measure of caloric availability based on information about where the meal was consumed in order to capture calories consumed by household members outside of the household. Indeed, one of the reasons that the NSS collects information about where calories are consumed is to overcome this potential problem. For the 1888CEX, however, such information is unnecessary. It is well known that members of

\footnotetext{
${ }^{6}$ As will be shown, the historical calorie estimates are greater than all of the estimates for developing countries, so doing such a comparison of one country would not explain why the finding holds for other countries.

${ }^{7}$ See Subramanian and Deaton (1996) for a discussion.
} 
industrial families in the late nineteenth century consumed nearly all their meals in their own households, where guests were infrequent and the diet monotonous. ${ }^{8}$

In Table 2, I reject the hypothesis that the historical expenditure elasticity of calories estimates fall within the range noted by Subramanian and Deaton in every specification of the expenditure elasticity of calories. In Subramanian and Deaton’s first specification, a regression of the log of per capita calories on the log of per capita expenditure, they obtain a point estimate near $.5 .^{9}$ In the historical regression of the log of per capita calories on the log of per capita expenditure the American point estimate is .61, and the British point estimate is .68, and I reject the hypothesis that either of the historical expenditure elasticities is less than or equal to .5. Even controlling for family size and the share of the household in five year age categories in the regression, where the American elasticity estimate is .55 and the British estimate is .62, I reject the same hypothesis.

In Subramanian and Deaton's fullest parametric specification of the model, they regress the log of per capita calories on the log of per capita expenditure, the log of family size, shares of the family by sex and age, and other covariates such as religion, caste, and geographic location. When I run a regression similar to theirs in Table 3 I continue to reject the hypothesis that the historical expenditure elasticities of calories are less than or equal to .5. When Subramanian and Deaton estimate the same regression their point estimate of the elasticity is .37, while for the United States the elasticity is .54 and for Great Britain it is .67. Not only are the historical estimates greater than Subramanian and Deaton's estimates, but they are, in the fullest model, greater than the largest of Subramanian and Deaton's elasticity estimates. Even in the fullest

\footnotetext{
${ }^{8}$ See Kertzer and Barbagli (2002), Byington (1910), and Chapin (1909).

${ }^{9}$ They in fact use a non-parametric technique and their global slope is close to .45.
} 
model, I continue to reject the hypothesis that the historical expenditure elasticity of calories estimates are less than or equal to .5.

An important caveat in this case study is measurement error. If there were only traditional measurement error in the 1888CEX it would imply that the historical elasticities are biased downward, and the strength of my conclusions would be enhanced since attenuation bias would imply that the historical estimates are too low. If, however, both calories and expenditure are measured with error, and if these errors are correlated, I will overstate the true expenditure elasticity of calories if the correlation between the errors dominates the attenuation bias. Bouis and Haddad (1992) have shown that when both types of measurement errors are present in a linear model of calorie demand the correlated measurement error dominates the attenuation bias. Subramanian and Deaton show, however, that if the log of non-food expenditure is used as an instrument for the log of per capita expenditure the resulting elasticity estimate is guaranteed to be biased downward even if there is correlated measurement error.

While OLS may be biased upwards depending on which type of measurement error dominates, and therefore constitutes an upper bound on the elasticity, the instrumented estimates will with certainty understate the expenditure elasticity of calories. Table 4 shows the upper and lower bound estimates of the expenditure elasticity of calories. As the table shows, the lower bound estimates for the historical elasticities, which fall to .45, are greater than Subramanian and Deaton's upper bound estimate for their calorie elasticity, which at it highest is .38. This result confirms that these historical estimates of the expenditure elasticity of calories are much larger than Subramanian and Deaton's estimates for India in 1983. The historical elasticities are out of the range of the elasticities for these Indian households in 1983. 


\section{B. Calorie Price Elasticities}

Another measure to compare, that is related to calorie elasticities, is the expenditure elasticity of calorie price. Earlier, I noted that the food elasticity is not a good quantifier of hunger since even well-fed people may have high food elasticities if they have high demand for expensive foods. Note, however, that the reverse should also hold. People who are very hungry should have relatively low expenditure elasticities of calorie price since they would desire increased quantity over quality. Also note that each household faces a unique price of calories based upon the quantity and types of foods that they consume, and this is easily estimated from the 1888CEX. Further, when one considers that the expenditure elasticity of food can be decomposed into the expenditure elasticity of calories (which we can take as a diet quantity measure) and the expenditure elasticity of calorie price (which we can take as a diet quality measure), the share of the food elasticity that is devoted to quantity will be larger for those who are hungry.

To see how this is achieved we can decompose the food expenditure elasticity. First, consider the expenditure elasticity of food, which is

$$
E\left[\ln \left(\text { foodbudget }_{i}\right)\right]=\alpha_{F}+\beta_{F} \ln \left(y_{i}\right)
$$

where $\mathrm{y}$ is expenditure per capita and $\beta_{F}$ is the expenditure elasticity of food expenditure. Note that total food expenditure is also total calorie expenditure, and it is the product of the price of the calories consumed by the household and the quantity of the calories consumed by the household. This gives the identity

$$
\text { foodbudget }_{i} \equiv P_{i} Q_{i}
$$


where $\mathrm{P}$ is the price of calories and Q is the quantity of calories. Note also that calorie price has an expenditure elasticity $\left(E\left[\ln \left(P_{i}\right)\right]=\alpha_{P}+\beta_{P} \ln \left(y_{i}\right)\right)$ and that the calorie quantity has an expenditure elasticity $\left(E\left[\ln \left(Q_{i}\right)\right]=\alpha_{Q}+\beta_{Q} \ln \left(y_{i}\right)\right)$. Taking the log of food identity and substituting the calorie price and calorie quantity elasticties into the food elasticity equation gives

$$
E\left[\ln \left(\text { foodbudget }_{i}\right)\right]=\alpha_{F}+\left(\beta_{P}+\beta_{Q}\right) \ln \left(y_{i}\right)
$$

where the slope of the food expenditure elasticity is simply the expenditure elasticity of calorie price added to the expenditure elasticity of calorie quantity and where $\alpha_{F}=\alpha_{P}+\alpha_{Q}$. As noted earlier, truly hungry people will increase the quantity of their calories more than those who are well fed, and this is why the size of the calorie elasticity, rather than the food elasticity, is the more appropriate measure of hunger. In looking at the share of the food elasticity devoted to calorie quantity, $\beta_{Q} /\left(\beta_{P}+\beta_{Q}\right)$, we can control for the overall size of the food elasticity. While it may be true that nearly all people will increase the price they pay for calories somewhat as their income increases, the share of the food elasticity devoted to increased quantity is a standardized way of looking at hunger that is very closely related to calorie elasticities and retains the calorie elasticity's intuitive appeal.

The price elasticities of calories further confirm the finding that workers in the late nineteenth century were worse off nutritionally than households in rural India in 1983. Table 5 shows the expenditure elasticity of calorie price for the American, British and Indian data. As we can see, the American and British price elasticities are much lower than the Indian price elasticities. While the Indian price elasticity is .32, the American price elasticity is .13, and the British price elasticity is .15 . Also, note that the hypothesis of price elasticity equality between 
the American and British households cannot be rejected. While Subramanian and Deaton find that the food elasticity is equally divided between the price elasticity and the calorie elasticity (so that roughly $50 \%$ of the food elasticity is due to increased quality), less than $25 \%$ of the food elasticity is due to the price elasticity for American and British industrial households in the late nineteenth century. More than 75\% of the food elasticity for American and British households was devoted to increasing the size of the diet, and less than a quarter to increasing the quality of the diet. Obviously, American and British households in the late nineteenth century were much more concerned with increasing the quantity of their calories than the quality of their calories.

While this comparison of calorie elasticities has established that those in contemporary India are better fed than American and British industrial workers in the late nineteenth century, this finding runs counter to the conclusions that economists have drawn about historical living standards from conventional income estimates. That a person in rural India in 1983 was betterfed than an American industrial worker a century before is surprising when one considers that American industrial workers were among the highest paid in the world at the time. If it is true that an American industrial worker in 1889 had nearly twice the purchasing power parity of a rural Indian in 1983, which is what our traditional income estimates tell us, then this result is

truly astounding. ${ }^{10}$ In less than a century some of the poorest people in the world are better fed than some of the wealthiest workers in the world were a century ago. From this case study I conclude that the press of hunger has undergone a significant transformation in the last century.

\section{Evidence from the General Pattern of Calorie Elasticities}

While the case study showed that the historical calorie elasticity estimates are greater than those living in Indian villages, the general pattern reveals that the historical estimates are 
indeed at the highest end of what is seen today for developing countries. In Table 6 I have listed the calorie elasticity estimates compiled by Strauss and Thomas (1995) that use a methodology similar to my own. Namely, each of the estimates in the table come from an OLS or two-stage least squares (2SLS) estimate of the calorie elasticity where the caloric unit is the number of calories available to the household and income and expenditure are the measures of household resources. Both the income and expenditure elasticity estimates for both Great Britain and the United States are among the highest estimates when compared to those compiled by Strauss and Thomas. Even when I instrument for expenditure using income, as Deaton (1997) has suggested in order to purge the expenditure elasticity of endogeneity, I find that an American worker in 1888 was as well-fed as a rural Indonesian, and only marginally better-fed than someone in Sri Lanka. The British worker is worst off of all-- they have the largest estimate of the expenditure elasticity of calories.

In looking at the general pattern it is important to note the role that urban and rural locations play in calorie elasticities. ${ }^{11}$ The households in the 1888CEX are generally urban households, while contemporary calorie elasticities are usually estimated for rural populations. In contemporary developing nations those in urban locations generally have lower caloric elasticities. Economic historians have established that rural households were better off than industrial, urban households in the past. Steckel (2001) notes that increasing urbanization has been blamed for the decline in living standards in the middle of the nineteenth century. In a broader survey, Steckel (1999) analyzed eight developed countries and finds that health was negatively correlated with urbanization throughout the industrialization process. Cuff (2005) has shown that those in remote locals in the antebellum period enjoyed a significant health advantage

\footnotetext{
${ }^{10}$ This estimate of PPP comes from the estimates of Officer (2001, 2002, and 2003) and McCusker (2003).
} 
over their urban contemporaries. With these considerations in mind, we can say that, a priori, urban households in late nineteenth century developed countries and rural households in developing countries will have the largest calorie elasticities for their times.

Demographic measures such as infant mortality and life expectancy support the notion that those in the late nineteenth century were worse off than those in developing countries today. Returning to the case study, we can note that while $90 \%$ of children born in 1983 Maharastra, India lived to see their fifth birthday, $80 \%$ did so in the United States, and only $75 \%$ did so in Great Britain. Similarly, life expectancy was also much shorter in the past. While males aged ten in the United States and Great Britain in the late nineteenth century could expect to live another 50 years, males aged ten in India in 1983 could expect to live another 55 years. ${ }^{12}$ In general, both infant mortality and life expectancy are much better today in developing countries than they were in the late nineteenth century.

When considering other estimates of well-being, such as height, the comparison between the past and present is more nuanced. Historically, the country with the taller population had greater per capita GDP and lower calorie elasticities. In the contemporary developing world, however, the relationship is not as straightforward. Development economists generally agree that, as a region, Sub-Saharan Africa has the lowest per capita GDP and highest calorie elasticities, and yet stature in many Sub-Saharan African nations is greater than many nations with much higher per capita GDP. ${ }^{13}$ There are several nations in Sub-Saharan Africa with statures that would make them taller than American and British industrial workers in the late

\footnotetext{
${ }^{11}$ Of course, what exactly is meant by "urban" and "rural” has changed over time, and even today their meaning can only be derived from context.

${ }^{12}$ While a five year life expectancy differential may appear small, changes in life expectancy at age ten require large reductions in later-life mortality that are much more difficult to achieve than reductions in infant mortality.

${ }^{13}$ It must be noted that ethnic and cultural differences in diet (namely, the propensity to eat significant amounts of animal protein) may explain the lack of a GDP-height relationship in developing countries today.
} 
nineteenth century, and others with shorter statures. ${ }^{14}$ South Asians, despite their better economic performance, are shorter than late nineteenth century industrial workers.

Due to the inherent problems of comparing point estimates of height, a look at the growth rate of average stature in centimeters per year would be more appropriate. ${ }^{15}$ Unfortunately, it is difficult to calculate a growth rate due to the lack of a general upward height trend in the developing world. Moradi (2002) analyzes height trends in Sub-Saharan Africa and South Asia from 1950 to 1980 . He finds that South Asians were making steady but slow height gains, but Sub-Saharan Africa had two nations where the height trend was increasing, nine with decreasing stature, one with a U shaped trend, and nine with inverted U shaped trends. These types of dissimilarities are not found in historical height trends. Indeed, A'Hearn (2003) and others have shown that the height trends of European nations moved very closely together even though they were at different stages in the industrialization process. Additionally, Steckel (2001) has shown that when height and per capita GDP diverged in the nineteenth century, they did so in nearly every nation of Western Europe and the United States. Since stature varies greatly from country to country toady without a clear short-run trend it is difficult to extend the comparison to stature.

\section{Considering the Validity of the Comparison}

The lessons and conclusions that we draw from the comparison of calorie elasticities are only as valid as the comparison itself. Here, I consider three objections to the comparisons of caloric elasticities across time and space. The comparisons made above would not be

\footnotetext{
${ }^{14}$ This comparison is made through the evidence presented by Moradi (2002) on heights, and assumes that industrial women in the late nineteenth century were 158 centimeters tall.
} 
appropriate if the estimates of calorie elasticities in the past are contaminated with indirect estimation bias, the failure to report home production of calories, or measurement error. In the end, we see that these objections, while potentially damaging, do not apply to the calorie elasticity comparisons made in this paper.

\section{A. The Indirect Estimates Objection}

The first objection to the comparison would be that the historical elasticity estimates are more indirect than the other estimates presented in Table 6. Indirect estimates of calorie elasticities are calculated by computing the income and/or expenditure elasticity of food for each respective food group and then converting that measure to calories. The problem with indirect estimates is that they miss the substitution that households make between foods within particular food groupings. Elasticity estimates derived using the indirect methods are usually greater than those that use the direct (calorie) method.

I do not believe that the historical estimates are contaminated with "indirect bias" for four reasons. First and foremost, Strauss and Thomas (1995) note that there is, a priori, nothing inherent in the indirect methodology that necessarily creates larger estimates-- in some studies a bias appears while in others it does not. While empirically caloric elasticities estimated with indirect estimates tend to be greater than direct estimates, this does not hold for every study. Secondly, food groups in the 1888CEX are fairly well detailed for the time of the survey, and I therefore capture a large amount of substitution between calorie groups. It is well established in the historical record that the diet of the working classes in the late nineteenth century was monotonous (Kertzer and Barbagli 2003). Third, for food groupings that were fairly broad (fruit,

\footnotetext{
${ }^{15}$ Comparing height at a point in time is analogous to comparing GDP at a point in time-it would be unreasonable to expect people who have only had fifty years of a stature transition to achieve the same heights as those whose
} 
for example), the calorie price of the foods in that group did not vary significantly by food group (calorie price of oranges versus calorie price of apples, for example). This means that substitution between goods within a food group were largely not substitutions towards more or less expensive calories, as far as we can calculate for the time. Lastly, looking at changes in food groups across the income distribution strongly suggest a great deal of substitution away from and towards different food groups. If the vast majority of the substitution was within a food group then the expenditure shares devoted to particular food groups would remain nearly constant from the top to bottom deciles of the income distribution, and this was clearly not the case. In fact, I find more substitution between food groups for industrial workers in the late nineteenth century than Subramanian and Deaton (1996) report for Indian households in 1983; this would not be true if the historical estimates were more indirect than their elasticity estimates. These four facts establish that the historical estimates are at least no more indirect than estimates from developing countries today.

\section{B. The Home Production of Calories Objection}

The second objection to the validity of the comparisons made in Table 6 has to do with the home production of calories. ${ }^{16}$ A home production objection notes that home-produced calories are not captured in the 1888CEX. Furthermore, if the distribution of home-produced calories is skewed towards the poorest families in the survey my estimates of available calories are too low for poor households. This yields calorie elasticity estimates that are too high in that they have systematically underestimated the total calories available to poorer households. I

\footnotetext{
statures have been growing for more than a century.

${ }^{16}$ This is attributed to Martha L. Olney, who reminded me that even in very urban locations it was not uncommon to have live animals, in particular chickens, in the backyard.
} 
should not, therefore, compare the 1888CEX calorie elasticity estimates to estimates that account for home production, as most studies in the developing world attempt to do.

It is true that the 1888CEX does not include home produced calories. I also agree that the distribution of home-produced calories is skewed towards poorer families, but only in the total population. The distribution within the 1888CEX, however, is not likely to be as skewed as the distribution in the general population. Furthermore, if the home production objection is valid, poor families would have food expeditures whose caloric content would be biased away from calories that are easily produced in the home (e.g. fruits and vegetables), and this is simply not found in the data. Finally, this argument implicitly assumes that the error in calories is correlated with income or expenditure, and we saw earlier that the result was robust to this sort of measurement error.

Narrative historical evidence cast doubt on the home production objection. In an insightful monograph, Byington (1910) conducted intensive interviews of nearly 100 families in a mill town near Pittsburgh, Pennsylvania near the turn of the century. She found that poor families lacked the income necessary to partake in significant home production, which runs counter to the assumption of the home production objection. In particular, Byington found that the poor families she studied bought their food in the market on a daily basis, while the wealthier families were able to buy in bulk and to buy whole animals (including chickens and pigs) since they had the income to provide for their storage. ${ }^{17}$ Furthermore, she found that dinner guests were infrequent in the households, indicating that calorie slippage (a significant number of available calories being provided to people who are not members of the household) is not a serious concern. In short, home production in the late nineteenth century required planning and 
savings which poor families could not afford. Furthermore, there is nothing in Byington's

evidence that suggests that poor industrial families produced calories in their homes in a way that wealthier industrial families could not or did not.

Additional narrative evidence supports Byington’s conclusions. Streightoff (1911) notes a study by Forman which found that very poor families in Washington "spend what little they have unwisely...these people never bought their own flour for breadmaking...and they seemed to ignore the value of such a cheap wholesome food as corn meal” (p. 99). He goes on to say that "some of the economies practiced among working families of the lowest rank are pitiful" (p. 100). He also found that perishables were rarely purchased far in advance since poor families could not afford ice. Chapin (1909) similarly found that "most families buy their supplies from day to day in very small quantities, partly from lack of facility for storing and keeping food, and partly from the lack of money enough at one time to enable them to buy any large amount” (p. 132). These studies strengthen Byington's claims about poor families and home production, and cast further doubt on the home production objection. The narrative evidence implies that any home production bias in the 1888CEX would lead to higher estimates of the caloric elasticities than those I have presented since it would be wealthy families whose calories are understated. Additional evidence that speaks to the home production argument is found in the 1888CEX itself. Within the 1888CEX interviewers commented on the general condition of the home and noted items that the family owns, including gardens, poultry, cows, and fruit trees. The comments were not uniform, however, and comments were not made for all households. Nevertheless, the comments can be used to identify the income distribution of home producing

\footnotetext{
${ }^{17}$ Byington also found that poor families lacked the money to buy ice by which they could store food. She also noted that these were the families who would be most helped by buying in bulk. Instead, these families were forced to live day to day and nearly all of the food they consumed was purchased in the market.
} 
households, and to learn if the income distributions of home producing and non-home producing households are similar. ${ }^{18}$

In a close analysis of the comments the results point in the opposite direction of the home production objection. ${ }^{19}$ The means of the log of per capita income and the log of per capita expenditure for both home producing and non-home producing households are very close to one another, and households with home production, as indicated in the comments, are found at all points of the income and expenditure distributions. Also, the income and expenditure distributions of home-producing and non-home producing households were very similar. In looking at the comments of the enumerators, I find no evidence that home production of calories is concentrated in low income households.

The strongest argument against the home production objection is as follows. Suppose that the poorest households-for convenience let us say the poorest third-- all participated in home production. I would therefore understate the total calories available to those households and overstate their expenditure elasticity of calories. Yet even if this were true the finding would hold. Estimates for the wealthier two thirds of households will be correct, and certainly for the top half they will be. Non-parametric expenditure elasticity estimates (not reported), which are based on small local neighborhoods of the log of per capita expenditure, will not be influenced by the failure to capture home production in the bottom third of households. ${ }^{20}$ Those results show that the average of the expenditure elasticity for the wealthier two-thirds of households still yields an estimate above .5 for the United States, and above .6 for the British. Therefore, even if I were to exclude the poorest third of households from the 1888CEX the historical elasticity

\footnotetext{
${ }^{18}$ It is important to note that the comments mentioned several types of household items, and occasionally made observations about the family and its organization and well-being. Given their detail, it is unlikely that comments systematically under-counted home production.

${ }^{19}$ Of course, these results are not decisive since the comments were not uniform.
} 
estimates would still be greater than what is seen in the developing world today. Indeed, to refute this point one would have to argue that nearly all households participated in home production, but this in turn would imply that the failure to capture home production is merely a level (in logs) effect which would not change the elasticity estimates. Given such strong narrative evidence and the lack of evidence from the comments of the interviewers, I do not see the home production objection as applying to the historical calorie elasticity estimates.

\section{The Measurement Error Objection}

The final objection to be considered is that the larger calorie elasticity for historical populations is primarily due to measurement error of income in contemporary developing countries. Essentially, this argument follows from the belief that household resources are poorly measured in developing countries today, and income measures are much worse than the measures available in the 1888CEX. As Deaton (1997) has noted, however, surveyors in developing countries have taken great pains to ensure that their measures are accurate. For example, the NSS does not ask for household income, as that question appeared to seriously hamper the response rate, and is difficult to measure for poor rural households. Indeed, one reason that expenditure, rather than income, is taken as the measure of household resources is that expenditure has less errors than income.

Turning to the particulars of this objection, measurement error could explain a small part of the results presented here, but to assert that they explain any significant portion of the differences in the elasticities one would have to take two contradictory positions. It could be true that expenditure is measured with more error in developing countries, but that would also mean that the greater errors in expenditure in developing countries would be (potentially) correlated

\footnotetext{
${ }^{20}$ For the non-parametric results see Logan (2005).
} 
with the errors in calories, resulting in even higher calorie elasticity estimates. As noted earlier, Bouis and Haddad (1992) have shown that in a linear model the correlated measurement error will usually be greater than the attenuation bias, leading to upwardly biased estimates of calorie elasticities when both types of errors are present. ${ }^{21}$ This implies that asserting that there is greater measurement error in contemporary developing countries is equivalent to stating that the calorie elasticity estimates for developing countries presented in Table 6 are too high. Section III showed that even the estimates for the United States and Great Britain that were too low by construction were greater than the estimates from India that may be plagued with correlated measurement error.

We can construct a reasonable bound for this measurement error with a simple calculation. First, consider the traditional errors-in-variables problem where the equation to be estimated is $y=\beta x+\varepsilon$ where $\mathrm{y}, \mathrm{x}, \beta$ and $\varepsilon$ are vectors and further assume that $x=\bar{x}+v$ where $\cup$ is orthogonal to the true $\bar{x}$. In reality, we would like to estimate $y=\beta \bar{x}+\varepsilon$ but the wellknown result is that the probability limit becomes $b=\beta\left(\frac{\sigma_{\bar{x}}^{2}}{\sigma_{\bar{x}}^{2}+\sigma_{v}^{2}}\right)$.

Using the case study for illustration, and noting that the relative variance is the important feature we can further assume that the variance in properly measured expenditure can be normalized to one so that $\sigma_{\bar{\chi}(U S)}^{2}=\sigma_{\bar{\chi}(G B)}^{2}=\sigma_{\bar{x}(\text { India })}^{2}=1$. Also, we can assume that the true elasticity, $\beta$ in the probability limit given above, is either the American or British expenditure elasticity of calories. Using the results of Table 3 we can use the probability limit to bound the measurement error to find how much measurement error there would have to be in the Indian data to explain the differences in the calorie elasticity estimates. Formally, what this measures is

${ }^{21}$ An important caveat here is that linearity appears to be a very good approximation to the actual relationship 
the proportional variance of the measurement error, $\sigma_{v}^{2}$, relative to the variance of expenditure properly measured, $\sigma_{\bar{x}}^{2}$, since we have normalized the variance of properly measured expenditure.

The arithmetic shows that the variance of the Indian measurement error must be almost half of properly measured expenditure variance $\left(\sigma_{v(\text { India })}^{2}=.5 \sigma_{\bar{x}(\text { India })}^{2}\right)$ for the true calorie elasticity in India to be equal to the American elasticity estimate, and the variance of the error must be nearly $85 \%$ of the properly measured expenditure variance $\left(\sigma_{v(\text { India })}^{2}=.85 \sigma_{\bar{x}(\text { India })}^{2}\right)$ for the British elasticity to be the true elasticity for India. Similarly, if we use the results of Table 4 and compare the lowest bound estimates of the historical expenditure elasticity of calories (which by construction are too low) to the upper bound of the Indian elasticities (which may be too high) we find that the variance of the Indian measurement error must be almost $20 \%$ of properly measured expenditure for the true elasticity in India to be equal to the American estimate, and the variance of the error must be nearly $35 \%$ of the properly measured expenditure variance for the British elasticity to be the true elasticity. Obviously, such an objection implies such implausibly high measurement error that it essentially argues that expenditures should not be measured at all in developing countries. Given the arithmetic, the objection is valid only if our methods of collecting microeconomic data at the household level have seriously deteriorated in the last one hundred years.

As this section has shown, the comparisons made in this paper are robust to indirect estimation bias, the failure to capture home production of calories, and measurement error. I therefore believe that the comparison advanced here is valid, legitimate, and useful. Even if my 
estimates were equal to what we observe in the developing world today the implication would be the same- the press of hunger has undergone a magnificent transformation in the last century.

\section{Calorie Demand, Engel Curves and New Income Estimates}

Moving beyond hunger, the findings in this paper tell us something about income estimates that may lead us to reexamine the reliability of our traditional estimates. In this section I return to Engel curves, and use the Engel curve suggested by the historical elasticity estimates to derive new income estimates for developing countries today based upon their calorie elasticities. The 1888CEX is unique in this regard because the survey allows us to specify a relationship between the calorie elasticities and aggregate income at a single point in time for two nations whose calorie elasticities are estimated in the same way.

The calorie elasticity-GDP per capita relationship is derived in the following way. First, I take the expenditure elasticity of calories estimates from Table 2 as our elasticity estimates for the United States and Great Britain. ${ }^{22}$ Secondly, I take the real 1889 GDP per capita estimates given by Ward and Devereux (2003). Since Ward and Devereux employ the use of an updated price index, their historical GDP estimates are more reliable than those that use long-span measures. Taking the elasticities and the income estimates gives us two points in calorie elasticity-real GDP per capita space. Using these two points in expenditure calorie elasticity-real GDP per capita space we can derive a linear Engel function relating the expenditure elasticity of calories to real GDP per capita in 1889. The income and elasticity values determine the line given by $\xi_{D}=1.324-.0035\left(G D P_{1889}\right)$. Figure 1 shows the line that fits the American and British elasticities and aggregate income estimates. It is noteworthy that this line is entirely plausible. 
Greater GDP per capita gives us lower calorie elasticities, and at very low levels of income the calorie elasticity will be very large, implying that food is a luxury at very low income levels. ${ }^{23}$

Since we know the expenditure elasticity of calories for developing countries in Table 6, we can place those calorie elasticities on the line given above to derive estaimates of real GDP per capita. This assumes that all of these elasticities lie on the same Engel curve, and from that we can derive income measures. The point of this exercise is not to argue that these real GDP estimates are the most accurate, but instead to stress the magnitude of the difference between traditional income estimates and those derived from this Engel curve. Table 7 reports both the traditional and the Engel derived estimates of GDP per capita for these nations whose expenditure elasticity of calories is reported in Table 6. The traditional GDP estimates listed in Table 7 are made by taking the real 1983 GDP per capita of the developing nations expressed in 1997 dollars and then dividing this by the purchasing power of a 1997 US dollar relative to that of a 1889 US dollar. ${ }^{24}$ As the table shows, there is a marked difference between the traditional and Engel based estimates of real GDP per capita. For example, Sri Lanka’s 1983 GDP per capita, under traditional estimates, is $\$ 19.20$ in 1889 US dollars. With the Engel derivation, however, their GDP per capita is \$218.29 in 1889 US dollars.

The factor of convergence reported in Table 7 is the amount that the traditional income estimates must be multiplied by to equal the new Engel based income estimates. Given the large factors of convergence in the table, it is safe to say that the Engel and purchasing power parity

\footnotetext{
${ }^{22}$ If one were to use the other historical elasticity estimates presented in this paper the income estimates for developing countries derived from the Engel curve would be even greater.

${ }^{23}$ This equation would also be consistent with an argument that before the Industrial Revolution caloric elasticities were close to one, assuming that real GDP grew at .5\% per year every year since 1740 .

${ }^{24}$ Another method would be to divide the real GDP expressed in 1997 dollars by the GDP deflator, and if those results were used the qualitative implications would be the same. The value of the deflator comes from Officer (2003). Also, the use of 1983 is to set the estimates of income at a point in time for specificity, and since it is a midpoint of the 1980-1985 GDP estimates. Similar income numbers are found when using the average of 19801985 real GDP and the average of 1975-1985 real GDP.
} 
(PPP) based estimates of real GDP per capita are not in line with one another. As the table shows, traditional income estimates understate the Engel income by a factor of more than six. The lowest factor of convergence in Table 7 is 6.93, for the Philippines, and the largest is 11.36, for Sri Lanka, with an average factor of convergence of more than 8.5. Note also that this same factor could be used to argue that historical income numbers for the United States and Great Britain are overstated by the same factor.

The traditional income estimates presented in Table 7 are not the only income estimates that the Engel-derived estimates can be compared to. Angus Maddison has produced the salient study of income estimates from the modern past to the present. The Engel derived income estimates are also greater than Maddison’s income estimates. For example, Maddison (1983) estimates that real GDP per capita in the Philippines in 1980 was $\$ 430$ in 1965 US dollars. The Engel derived estimates find that real 1980 GDP per capita in the Philippines was \$778 1965 US dollars, more than $80 \%$ greater than Maddison's estimates. ${ }^{25}$ While this difference is not as large as the factor of convergence values in Table 7, it is still a substantial revision of the real GDP per capita estimate for the Philippines in 1980.

Even further, the Engel-based income estimates yield income estimates for poor countries that are out of the range of real GDP estimates produced using a number of traditional methods. Keeping with the example of the Philippines, Maddison (1983) gives the real GDP per capita of the Philippines in 1965 as a percentage of American real GDP in 1965 under a number of different weighting schemes. ${ }^{26}$ None of the schemes give 1965 Philippino GDP as more than 12.6\% of American GDP in 1965. Engel-income, however, estimate that Philippino real GDP

\footnotetext{
${ }^{25}$ I took the Engel based 1983 real GDP estimate and used Maddison's (1983) estimates of real GDP growth for the Philippines to compute Engel derived real GDP estimates for the Philippines for 1965, 1975, and 1980.

${ }^{26}$ These include using the official exchange rate, 1965 US prices, 1975 multilateral weights, and 1970 multilateral rates.
} 
was more than $19 \%$ of American GDP per capita in 1965. Similarly, while various methods estimate Philippino real GDP per capita in 1975 as no more than 15.9\% of American GDP in 1975, the Engel estimates find that Philippino GDP was 17.7\% of Americn GDP in 1975. ${ }^{27}$

What does this mean for estimates of economic growth? If the Engel based income estimates are correct then economic growth has been understated. Understatement could occur in two ways, although neither is exclusive of the other. Either American and British economic growth from the late nineteenth century to the present or the economic growth of developing countries since the end of the Second World War has been seriously understated. Both of these types of misestimates would drive the type of anomalies described here, assuming that contemporary estimates of GDP per capita are estimated properly.

What does this mean for estimates of well-being? There is a fundamental difference between calorie elasticities, which quantify hunger, and GDP, which is the value of all goods and services produced in the economy. As such, GDP tells us something very different about the economy than calorie elasticities. GDP tells us how productive the labor (population), capital and technology are in the economy, while calorie elasticities give us a summary measure of the demand for one of life's most basic necessities. Since these two measures purport to tell us different, but related, things, we should not be surprised when they do not agree. The open question, however, is how far apart the measures should be if we are to hold to the belief that they are related to one another.

The basic conclusion from the Engel analysis is that our measures of living standards should be consistent, and when marked inconsistencies occur we should re-evaluate what our measures purport to tell us. Calorie elasticities give us a microeconomic way of assessing living

\footnotetext{
${ }^{27}$ The weighting schemes for 1975 real GDP include exchange rates, own-country weights, United States weights, and multilateral weights.
} 
standards over time and space wholly within the economic apparatus. If the elasticities are not in line with our PPP estimates, we should not be surprised. At a minimum, this Engel analysis suggests that our PPP based estimates need to be revised. While one objection to such a conclusion would be that there are different prices, different bundles, and different taste over time and space, PPP has been advanced as a method to deal with such differences. This Engel analysis also suggests that our PPP estimates perform very poorly over time. Indeed, the way that our PPP estimates are constructed, as an interconnected web of between-country comparisons, certainly give rise to large discrepancies across space. When one combines this with the traditional methodology used to derive historical GDP estimates, where the price index is set at a point in time and then GDP is regressed on growth rates to derive historical real GDP, we are bound to get estimates that may be off by large factors over time. Calorie elasticities may not be the best estimate, but the conclusions drawn from the Engel curve suggest that they may be a better estimate than our PPP estimates if our goal is to quantify changes in human living standards over time.

\section{Conclusion}

In his Nobel Address, Robert Fogel (1994a) suggested that economists use the insights of economic historians as they devise economic policy.

Failure to take account of economic history...has often led to a misunderstanding of current economic problems by investigators who have not realized that their generalizations rested upon transient circumstances. Nowhere is the need to recognize the role of long-run dynamics more relevant than in such pressing current issues as medical care, pension policies, and development policies (p. 1).

This paper furthers the case that economic history has important implications for contemporary economic problems and for the way that we measure economic well-being over time and space. 
That the dynamics of the increasing quality of human life fail to be captured in conventional growth estimates adds further impetus to the recent suggestions that quality of life measures be incorporated into discussions of growth. Indeed, Deaton (2005) has recently argued that current growth estimates overstate economic growth and understate poverty reduction in poor countries.

The empirical results in this paper establish a number of facts. First and foremost, people in developing countries today are well fed in comparison to yesterday's industrial workers. Secondly, calorie elasticities have an intuitive appeal and their interpretation is robust to a number of objections that would seriously damage comparisons of other measures of nutritional well-being. Lastly, hunger-based estimates of aggregate income tell us a very different story about the well-being of people in developing countries today, and also imply that economic growth has been understated.

I have argued in this paper that calorie elasticity differentials are real and meaningful, and that there has been a magnificent transformation of hunger over time. Some of the poorest people in the developing world today are better off, by this nutritional estimate, than industrial workers a century ago, even though these late nineteenth century industrial workers are wealthier than those in the developing world today. Indeed, the question now is not "Why are caloric elasticities in the developing world so high?” but "How did caloric elasticities in the developing world get so low?" To that end, more historical microeconomic measures of nutrition would be helpful, and when they are absent analytic narratives may help us understand the historical dynamics of hunger in developing nations.

What are we to make of the finding that the poor of today are quite well fed when compared to the relatively wealthy only a century ago? A rapidly declining price of calories may be the answer to the empirical puzzle presented here. Indeed, some rough estimates presented in 
this essay suggest that the price of calories has declined dramatically over the last century. Given the Green Revolution, transportation innovations, and increasing technological sophistication of agriculture in developing countries in the second half of the last century, we should expect the price of calories to be relatively low in developing nations when compared to the price of calories faced by the historical households analyzed in this paper.

Even with this open question these findings give us hope that the defeat of hunger is closer than many have previously thought, and they are in line with the calls to eliminate extreme poverty in twenty years (Sachs 2005). Both the American and British economies grew quickly between 1890 and 1920, and strong economic growth played a significant role in filling hungry stomachs during that time. While this paper has painted an optimistic picture of hunger in developing countries, it must be made clear that hunger continues to exact a devastating toll on the world. In 2002 the World Health Organization listed hunger as the number one health risk in the world, accounting for an estimated 3.4 million deaths in 2000, nearly all of which occurred in poor countries. The open question is what policies will eliminate hunger once and for all. History provides some clues as to which track to take, but it is up to contemporary policy makers to use the lessons of economic history effectively. 


\section{References}

A’Hearn, Brian. (2003) “Anthropometric Evidence on Living Standards in Northern Italy, 17301860.” Journal of Economic History 63: 351-381.

Bouis, Howarth E. and Lawrence J. Haddad (1992). “Are Estimates of Calorie-Income Elasticities Too High? A Recalibration of the Plausible Range.” Journal of Development Economics 39: 333-364.

Byington, Margaret F. (1910). Homestead: The Households of a Mill Town. Philadelphia: W.M. Fell Co.

Chapin, Robert Coit. (1909). The Standard of Living Among Workingmen's Families in New York City. New York: Charities Publication.

Cuff, Timothy (2005). The Hidden Cost of Economic Development: The Biological Standard of Living in Antebellum Pennsylvania. Burlington, VT: Ashgate.

Deaton, Angus. (1997). The Analysis of Household Surveys: A Microeconometric Approach to Development Policy. Baltimore: Johns Hopkins. . (2005). "Measuring Poverty in a Growing World (or Measuring Growth in a Poor World.)” The Review of Economics and Statistics 87: 1-19.

Fogel, Robert W. (1994a). "Economic Growth, Population Theory, and Physiology: The Bearing of Long-Term Processes on the Making of Economic Policy.” NBER Working Paper No. 4638. . (1994b). "Economic Growth, Population Theory, and Physiology: The Bearing of LongTerm Processes on the Making of Economic Policy.” American Economic Review 84: 369395.

Fogel, Robert W. and Stanley L. Engerman. (1974). Time on the Cross: Evidence and Methods. Boston: Little, Brown and Co.

Haines, Michael R. (1979). “Industrial Work and the Family Life Cycle.” Research in Economic History 4: 289-356.

Johnston, Louis and Samuel H. Williamson. (2003). "The Annual Real and Nominal GDP for the United States, 1789 - 2002." Economic History Services, URL : http://www.eh.net/hmit/gdp/.

Kertzer, David, I. and Marzio Barbagli, eds. (2002). The History of the European Family, Volume 2 Family Life in the Long Nineteenth Century. New Haven, CT: Yale University Press.

Lees, Lynn H. (1979). “Getting and Spending: The family Budgets of English Industrial Workers in 1890.” in John Merriman, ed. Consciousness and Class Experience in Nineteenth Century Europe. New York: Holmes and Meier: 169-186.

Logan, Trevon D. (2005). “Nutritional and Well-Being in the Late Nineteenth Century.” Mimeo, The Ohio State University.

Maddison, Angus (1983). “A Comparison of Levels of GDP Per Capita in Developed and Developing Countries, 1700-1980.” Journal of Economic History 43: 27-41. . (1995). Monitoring the World Economy 1820-1992. Paris: Development Centre of the OECD. 
McCusker, John J. (2003). "Comparing the Purchasing Power of Money in the United States (or Colonies) from 1665 to 2002.” Economic History Services, URL:

http://www.eh.net/hmit/ppowerusd

Mirrlees, James A. (1975). “A Pure Theory of Underdeveleoped Economies.” in Lloyd G. Reynolds, ed. Agriculture in Development Theory. New Haven: Yale University Press.

Modell, John. (1978). "Patterns of Consumption, Acculturation, and Family Income Strategies in Late Nineteenth-Century America.” in Tamara K. Hareven and Maris A. Vinovskis, eds. Family and Population in Nineteenth Century America. Princeton, NJ: Princeton University Press: 206-240.

Moradi, Alexander. (2002). "Height and Health of Women in Sub-Saharan Africa and South-Asia 1950-1980.” Mimeo, University of Tuebingen.

Nutribase (2001). The Nutribase Complete Book for Food Counts. New York: Avery.

Officer, Lawrence H. (2001), "Exchange Rate Between the United States Dollar and the British Pound, 1791-2000." Economic History Services, URL: http://www.eh.net/hmit/exchangerates/pound.php . (2002). "Exchange Rate Between the United States Dollar and Forty Other Countries 19131999.” Economic History Services, URL: http://www.eh.net/hmit/exchangerates . (2003). "The Annual Real and Nominal GDP for the United Kingdom, 1086 - 2000." Economic History Services, URL: http://www.eh.net/hmit/ukgdp/

Ruiz-Arranz, Marta, et. al. (2002) "More Calories or More Diversitry? An Econometric Evaluation of the Impact of the PROGRESA and PROCAMPO Transfer Programs on Food Security in Rural Mexico.” Mimeo, Harvard University.

Sachs, Jeffrey G. (2005). The End of Poverty: Economic Possibilities for Our Time. New York: Penguin Press.

Shergold, Peter R. (1982). Working-Class Life: The "American Standard" in Comparative Perspective 1899-1913. Pittsburgh, PA: Pittsburgh University Press.

Steckel, Richard H. (1986). (1999). “Industrialization and Health in Historical Perspective.” NBER Working Paper No. h0118. . (2001). "Health and Nutrition in the Preindustrial Era: Insights from a Millenium of Average Heights in Northern Europe.” NBER Working Paper No. 8542.

Stigler, George J. (1954). “The Early History of Empirical Studies of Consumer Behavior.” Journal of Political Economy 42: 95-113.

Stiglitz, Joseph E. (1976). “The Efficiency Wage Hypothesis, Surplus Labour, and the Distribution of Income in L.D.C.s.” Oxford Economic Papers 28: 185-207.

Strauss, John and Duncan Thomas. (1995). "Human Resources: Empirical Modeling of Household and Family Decisions.” in Jere Behrman and T.N. Srinivasan, eds., Handbook of Development Economics. Amsterdam: Elsevier, 1883-2023. . (1998). "Health, Nutrition, and Economic Development.” Journal of Economic Literature 36: 766-817. 
Streightoff, Frank Hatch. (1911). The Standard of Living Among the Industrial People of America. New York: Houghton Mifflin.

Subramanian, Shankar and Angus Deaton. (1996). “The Demand for Food and Calories.” Journal of Political Economy 104: 133-162.

U.S. Department of Labor. "Cost of Living of Industrial Workers in the United States and Europe 1888-1890.” Study No. 7711. Ann Arbor, MI: ICPSR.

U.S. Senate Committee on Finance. (1892). "Retail Prices and Wages: A Report by Mr. Aldrich.” U.S. Senate Report No. 986. Washington, DC: Government Printing Office.

Ward, Marianne and John Devereux (2003). "Measuring British Decline: Direct Versus Long-Span Income Measures.” Journal of Economic History 63: 826-851.

World Health Organization. (2002). The World Health Report 2002. Geneva: WHO Publications. 


\section{Table1}

Summary Dietary Measures

Number of Calories Per Head

$\begin{array}{cccc} & \text { US } & \text { GB } & \text { India* }^{*} \\ & 1888 & 1888 & 1983 \\ \text { Calories Per Head } & 1,646 & 1,390 & 2,098\end{array}$

Percent of Total Household Expenditure Devoted to Food

$\begin{array}{ccc}\text { US } & \text { GB } & \text { India* } \\ 1888 & 1888 & 1983\end{array}$

Percent of Budget

Devoted to Food

$44.50 \%$

$50.10 \%$

$67.40 \%$

\section{Price of a Day's Worth of Calories as a Percentage of a Day's Wage}

$\begin{array}{lccc}\text { Industry } & \text { US } & \text { GB } & \begin{array}{c}\text { India } \\ \text { P* }\end{array} \\ \text { Pig Iron } & 1888 & 1888 & 1983 \\ \text { Bar Iron } & 11.25 \% & 16.96 \% & - \\ \text { Steel } & 8.26 \% & 14.49 \% & - \\ \text { Bitminous Coal } & 9.98 \% & 12.97 \% & - \\ \text { Coke } & 13.53 \% & 16.88 \% & - \\ \text { Iron Ore } & 11.18 \% & 19.70 \% & - \\ \text { Cotton Textile } & 17.88 \% & - & - \\ \text { Wool Textile } & 15.92 \% & 16.66 \% & - \\ \text { Glass } & 12.18 \% & 20.01 \% & - \\ & 7.45 \% & 14.97 \% & - \\ \text { Average } & & & \\ \end{array}$

The percentage is the proportion of a husband's daily wage, in each industry, that would purchase 2,300 calories at the average calorie price faced by households in each industry.

* Results come from Subramanian and Deaton (1996), pg. 140, Table 1

* Results come from Subramanian and Deaton (1996) p. 155, and are for 2,600 calories at average prices for Maharastra, India in 1983. 


\section{Table 2}

Log-Log Transformation OLS Estimates of Caloric Elasticities, 1888 Cost of Living Survey (Dependent Variable $=$ Log of Per Capita Calories $($ InPCC) $)$

\begin{tabular}{|c|c|c|c|c|c|c|c|c|}
\hline & I & II & III & IV & V & VI & VII & VIII \\
\hline & GB & GB & GB & GB & US & US & US & US \\
\hline Intercept & $\begin{array}{l}7.555 \\
(.203)\end{array}$ & $\begin{array}{l}6.779 \\
(.229)\end{array}$ & $\begin{array}{l}8.477 \\
(.328)\end{array}$ & $\begin{array}{l}7.289 \\
(.388)\end{array}$ & $\begin{array}{l}8.836 \\
(.067)\end{array}$ & $\begin{array}{l}7.478 \\
(.067)\end{array}$ & $\begin{array}{c}10.057 \\
(.094)\end{array}$ & $\begin{array}{l}8.140 \\
(.097)\end{array}$ \\
\hline $\operatorname{lnPCl}$ & $\begin{array}{l}0.595 \\
(.022)\end{array}$ & & $\begin{array}{l}0.502 \\
(.032)\end{array}$ & & $\begin{array}{l}0.465 \\
(.007)\end{array}$ & & $\begin{array}{l}0.358 \\
(.009)\end{array}$ & \\
\hline InPCE & & $\begin{array}{l}0.684 \\
(.025)\end{array}$ & & $\begin{array}{l}0.624 \\
(.039)\end{array}$ & & $\begin{array}{l}0.613 \\
(.007)\end{array}$ & & $\begin{array}{l}0.550 \\
(.009)\end{array}$ \\
\hline InFamSize & & & $\begin{array}{l}0.020 \\
(.034)\end{array}$ & $\begin{array}{l}0.086 \\
(.036)\end{array}$ & & & $\begin{array}{c}-0.078 \\
(.012)\end{array}$ & $\begin{array}{l}0.016 \\
(.011)\end{array}$ \\
\hline Share $0-4^{*}$ & & & $\begin{array}{c}-0.330 \\
(.076)\end{array}$ & $\begin{array}{l}-0.311 \\
(.075)\end{array}$ & & & $\begin{array}{c}-0.358 \\
(.025)\end{array}$ & $\begin{array}{l}-0.339 \\
(.022)\end{array}$ \\
\hline Share 5-9* & & & $\begin{array}{l}-0.271 \\
(.079)\end{array}$ & $\begin{array}{r}-0.272 \\
(.078)\end{array}$ & & & $\begin{array}{c}-0.256 \\
(.028)\end{array}$ & $\begin{array}{l}-0.243 \\
(.025)\end{array}$ \\
\hline Share $10-14^{*}$ & & & $\begin{array}{c}-0.095 \\
(.085)\end{array}$ & $\begin{array}{l}-0.126 \\
(.083)\end{array}$ & & & $\begin{array}{r}-0.197 \\
(.032)\end{array}$ & $\begin{array}{l}-0.211 \\
(.028)\end{array}$ \\
\hline Share $15-19^{*}$ & & & $\begin{array}{c}-0.048 \\
(.085)\end{array}$ & $\begin{array}{l}-0.026 \\
(.087)\end{array}$ & & & $\begin{array}{l}0.052 \\
(.034)\end{array}$ & $\begin{array}{l}0.003 \\
(.030)\end{array}$ \\
\hline Share $20-24^{*}$ & & & $\begin{array}{l}0.060 \\
(.050)\end{array}$ & $\begin{array}{l}0.046 \\
(.049)\end{array}$ & & & $\begin{array}{l}0.086 \\
(.023)\end{array}$ & $\begin{array}{l}0.033 \\
(.022)\end{array}$ \\
\hline R-Square & 0.48 & 0.50 & 0.50 & 0.52 & 0.44 & 0.56 & 0.49 & 0.58 \\
\hline \multicolumn{9}{|c|}{$\begin{array}{l}\mathrm{N}=6809 \text { for all US Regressions, } 1024 \text { in all Great Britain Regressions } \\
\text { Mean of InPCC = } 13.2049 \text { in US, } 13.0739 \text { in Great Britain } \\
\text { Each column is a separate OLS regression in which InPCC was the dependent variable. } \\
\text { Robust standard errors are listed under coefficient estimates in parentheses. } \\
\text { * Share } x-y \text { is the share (proportion) of the household aged } x \text { to y. }\end{array}$} \\
\hline
\end{tabular}




\section{Table 3}

Log-Log Transformation OLS Estimates of Caloric Elasticities 1888 United States, 1888 Great Britain, and 1983 India

\begin{tabular}{|c|c|c|c|c|c|c|}
\hline & US & GB & US & GB & India* & India* \\
\hline & 1888 & 1888 & 1888 & 1888 & 1983 & 1983 \\
\hline & 1 & II & III & IV & V & VI \\
\hline Intercept & $\begin{array}{c}10.239 \\
(.109)\end{array}$ & $\begin{array}{l}8.184 \\
(.323)\end{array}$ & $\begin{array}{l}8.014 \\
(.119)\end{array}$ & $\begin{array}{l}6.814 \\
(.378)\end{array}$ & $\begin{array}{l}6.028 \\
(.077)\end{array}$ & \\
\hline $\ln \mathrm{PCl}$ & $\begin{array}{l}0.325 \\
(.010)\end{array}$ & $\begin{array}{l}0.535 \\
(.032)\end{array}$ & & & & \\
\hline InPCE & & & $\begin{array}{l}0.543 \\
(.011)\end{array}$ & $\begin{array}{l}0.674 \\
(.038)\end{array}$ & $\begin{array}{l}0.366 \\
(.013)\end{array}$ & $\begin{array}{l}0.341 \\
(.013)\end{array}$ \\
\hline InFamSize & $\begin{array}{c}-0.135 \\
(.013)\end{array}$ & $\begin{array}{l}0.009 \\
(.047)\end{array}$ & $\begin{array}{l}-0.033 \\
(.011)\end{array}$ & $\begin{array}{l}0.090 \\
(.048)\end{array}$ & $\begin{array}{l}-0.157 \\
(.011)\end{array}$ & $\begin{array}{l}-0.163 \\
(.008)\end{array}$ \\
\hline Male 0-4 & $\begin{array}{c}-0.271 \\
(.041)\end{array}$ & $\begin{array}{l}-0.226 \\
(.146)\end{array}$ & $\begin{array}{l}-0.225 \\
(.038)\end{array}$ & $\begin{array}{l}-0.212 \\
(.144)\end{array}$ & $\begin{array}{l}-0.097 \\
(.044)\end{array}$ & $\begin{array}{l}-0.146 \\
(.036)\end{array}$ \\
\hline Male 5-9 & $\begin{array}{c}-0.178 \\
(.043)\end{array}$ & $\begin{array}{l}-0.182 \\
(.156)\end{array}$ & $\begin{array}{l}-0.114 \\
(.039)\end{array}$ & $\begin{array}{l}-0.183 \\
(.155)\end{array}$ & $\begin{array}{l}0.049 \\
(.041)\end{array}$ & $\begin{array}{l}0.032 \\
(.032)\end{array}$ \\
\hline Male $10-14$ & $\begin{array}{c}-0.098 \\
(.042)\end{array}$ & $\begin{array}{l}-0.052 \\
(.158)\end{array}$ & $\begin{array}{l}-0.087 \\
(.039)\end{array}$ & $\begin{array}{l}-0.102 \\
(.156)\end{array}$ & $\begin{array}{l}0.089 \\
(.047)\end{array}$ & $\begin{array}{l}0.061 \\
(.032)\end{array}$ \\
\hline Male 15-55 & $\begin{array}{l}0.198 \\
(.045)\end{array}$ & $\begin{array}{l}-0.040 \\
(.138)\end{array}$ & $\begin{array}{l}0.162 \\
(.040)\end{array}$ & $\begin{array}{l}-0.057 \\
(.140)\end{array}$ & $\begin{array}{l}0.164 \\
(.032)\end{array}$ & $\begin{array}{l}0.163 \\
(.028)\end{array}$ \\
\hline Male 55+ & $\begin{array}{l}0.083 \\
(.042)\end{array}$ & $\begin{array}{l}0.063 \\
(.161)\end{array}$ & $\begin{array}{l}0.120 \\
(.038)\end{array}$ & $\begin{array}{l}0.084 \\
(.152)\end{array}$ & $\begin{array}{l}0.141 \\
(.047)\end{array}$ & $\begin{array}{l}0.121 \\
(.043)\end{array}$ \\
\hline Female 0-4 & $\begin{array}{c}-0.266 \\
(.040)\end{array}$ & $\begin{array}{l}-0.260 \\
(.143)\end{array}$ & $\begin{array}{l}-0.219 \\
(.036)\end{array}$ & $\begin{array}{l}-0.248 \\
(.142)\end{array}$ & $\begin{array}{l}-0.136 \\
(.044)\end{array}$ & $\begin{array}{l}-0.187 \\
(.038)\end{array}$ \\
\hline Female 5-9 & $\begin{array}{c}-0.159 \\
(.043)\end{array}$ & $\begin{array}{l}-0.255 \\
(.147)\end{array}$ & $\begin{array}{l}-0.131 \\
(.038)\end{array}$ & $\begin{array}{l}-0.274 \\
(.147)\end{array}$ & $\begin{array}{l}0.018 \\
(.044)\end{array}$ & $\begin{array}{l}-0.004 \\
(.040)\end{array}$ \\
\hline Female $10-14$ & $\begin{array}{r}-0.117 \\
(.047)\end{array}$ & $\begin{array}{l}-0.037 \\
(.157)\end{array}$ & $\begin{array}{l}-0.121 \\
(.042)\end{array}$ & $\begin{array}{l}-0.065 \\
(.155)\end{array}$ & $\begin{array}{l}0.114 \\
(.041)\end{array}$ & $\begin{array}{l}0.068 \\
(.034)\end{array}$ \\
\hline Female 15-55 & $\begin{array}{l}0.098 \\
(.039)\end{array}$ & $\begin{array}{l}0.032 \\
(.132)\end{array}$ & $\begin{array}{l}0.054 \\
(.036)\end{array}$ & $\begin{array}{l}0.023 \\
(.131)\end{array}$ & $\begin{array}{l}0.042 \\
(.026)\end{array}$ & $\begin{array}{l}0.051 \\
(.025)\end{array}$ \\
\hline R-Square & 0.58 & 0.54 & 0.64 & 0.57 & 0.55 & 0.67 \\
\hline $\mathrm{N}$ & 6,809 & 1,024 & 6,809 & 1,024 & 5,624 & 5,624 \\
\hline Industry Dummies? & Yes & Yes & Yes & Yes & Yes & Yes \\
\hline State/Region Dumm & Yes & No & Yes & $N A^{* *}$ & No & Yes \\
\hline
\end{tabular}

* Results come from Subramanian and Deaton (1996) Table 2, p. 153.

${ }^{\star *}$ Note: Geographic detail is not available for the British sample

Male/Female $x-y$ is the share (proportion) of the household that is in that age-sex category.

Each column is a separate OLS regression in which InPCC was the dependent variable.

Robust standard errors are listed under coefficient estimates in parentheses. 


\section{Table 4}

Upper and Lower Bound Expenditure Elasticity of Calories Estimates

$\begin{array}{lllcccccc} & \begin{array}{c}\text { Dependent } \\ \text { Variable }\end{array} & \begin{array}{c}\text { Independent } \\ \text { Variable }\end{array} & \begin{array}{c}\text { Instrumental } \\ \text { Variables }\end{array} & \text { Upper Bound } & \text { Lower Bound } \\ \text { Great Britain, } 1888 & \text { InPCC } & \text { InPCE } & \text { InNFE, InTIF } & 0.722 & (.031) & 0.512 & (.031) \\ \text { United States, 1888 } & \text { InPCC } & \text { InPCE } & \text { InNFE, InTIF } & 0.594 & (.009) & 0.450 & (.009) \\ \text { India, 1983* } & \text { InPCC } & \text { InPCE } & \text { InNFE } & 0.439 & (.006) & 0.334 & (.009) \\ \text { India, 1983* } & \text { InPCC } & \text { InPCE } & \text { InNFE, InTIF } & 0.378 & (.006) & 0.281 & (.008)\end{array}$

* Results come from Subramanian and Deaton (1996) Table 3, p. 160. InNFE is the log of total non-food expenditure, and InTIF is the log of household size. InTIF was used as an instrument for itself. Standard errors are in parentheses.

Upper bounds come from OLS estimates of InPCC on InPCE, InTIF regressions. Lower bounds are IV regressions with the same variables as OLS, with InNFE as the instrument for InPCE. 


\section{Table 5}

Log-Log OLS Estimates of Elasticity of Calorie Price for United States, Great Britain, and India (Dependent Variable $=$ Log of Calorie Price)

\begin{tabular}{|c|c|c|c|c|c|c|}
\hline & $\begin{array}{c}\text { US } \\
1888 \\
\text { I }\end{array}$ & $\begin{array}{c}\text { GB } \\
1888 \\
\text { II }\end{array}$ & $\begin{array}{c}\text { US } \\
1888 \\
\text { III }\end{array}$ & $\begin{array}{c}\text { GB } \\
1888 \\
\text { IV }\end{array}$ & $\begin{array}{c}\text { India* } \\
1983 \\
\text { V }\end{array}$ & $\begin{array}{c}\text { India* } \\
1983 \\
\text { VI }\end{array}$ \\
\hline Intercept & $\begin{array}{l}-3.828 \\
(.056)\end{array}$ & $\begin{array}{l}-3.995 \\
(.207)\end{array}$ & $\begin{array}{c}-3.401 \\
(.087)\end{array}$ & $\begin{array}{c}-3.588 \\
(.291)\end{array}$ & $\begin{array}{l}-1.593 \\
(.089)\end{array}$ & \\
\hline InPCE & $\begin{array}{l}0.156 \\
(.006)\end{array}$ & $\begin{array}{l}0.187 \\
(.022)\end{array}$ & $\begin{array}{l}0.126 \\
(.008)\end{array}$ & $\begin{array}{l}0.147 \\
(.028)\end{array}$ & $\begin{array}{l}0.380 \\
(.015)\end{array}$ & $\begin{array}{l}0.322 \\
(.014)\end{array}$ \\
\hline InFamSize & & & $\begin{array}{r}-0.012 \\
(.009)\end{array}$ & $\begin{array}{l}-0.077 \\
(.036)\end{array}$ & $\begin{array}{l}0.084 \\
(.012)\end{array}$ & $\begin{array}{l}0.066 \\
(.008)\end{array}$ \\
\hline Male 0-4 & & & $\begin{array}{l}0.010 \\
(.027)\end{array}$ & $\begin{array}{l}0.091 \\
(.112)\end{array}$ & $\begin{array}{l}0.102 \\
(.045)\end{array}$ & $\begin{array}{l}0.101 \\
(.031)\end{array}$ \\
\hline Male 5-9 & & & $\begin{array}{r}-0.052 \\
(.029)\end{array}$ & $\begin{array}{l}0.171 \\
(.116)\end{array}$ & $\begin{array}{l}-0.047 \\
(.039)\end{array}$ & $\begin{array}{l}-0.033 \\
(.028)\end{array}$ \\
\hline Male $10-14$ & & & $\begin{array}{c}-0.024 \\
(.030)\end{array}$ & $\begin{array}{l}0.136 \\
(.125)\end{array}$ & $\begin{array}{l}-0.112 \\
(.049)\end{array}$ & $\begin{array}{l}-0.084 \\
(.029)\end{array}$ \\
\hline Male 15-55 & & & $\begin{array}{c}-0.151 \\
(.030)\end{array}$ & $\begin{array}{l}0.113 \\
(.111)\end{array}$ & $\begin{array}{l}-0.170 \\
(.039)\end{array}$ & $\begin{array}{l}-0.135 \\
(.027)\end{array}$ \\
\hline Male 55+ & & & $\begin{array}{c}-0.046 \\
(.029)\end{array}$ & $\begin{array}{l}0.019 \\
(.104)\end{array}$ & $\begin{array}{l}-0.157 \\
(.044)\end{array}$ & $\begin{array}{l}-0.107 \\
(.037)\end{array}$ \\
\hline Female 0-4 & & & $\begin{array}{c}-0.013 \\
(.027)\end{array}$ & $\begin{array}{l}0.120 \\
(.113)\end{array}$ & $\begin{array}{l}0.046 \\
(.042)\end{array}$ & $\begin{array}{l}0.074 \\
(.034)\end{array}$ \\
\hline Female 5-9 & & & $\begin{array}{l}0.055 \\
(.029)\end{array}$ & $\begin{array}{l}0.197 \\
(.113)\end{array}$ & $\begin{array}{l}-0.064 \\
(.046)\end{array}$ & $\begin{array}{l}-0.048 \\
(.034)\end{array}$ \\
\hline Female 10-14 & & & $\begin{array}{c}-0.054 \\
(.031)\end{array}$ & $\begin{array}{l}0.058 \\
(.124)\end{array}$ & $\begin{array}{l}-0.111 \\
(.041)\end{array}$ & $\begin{array}{l}-0.087 \\
(.029)\end{array}$ \\
\hline Female 15-55 & & & $\begin{array}{c}-0.110 \\
(.025)\end{array}$ & $\begin{array}{l}0.107 \\
(.104)\end{array}$ & $\begin{array}{l}0.009 \\
(.028)\end{array}$ & $\begin{array}{l}-0.002 \\
(.021)\end{array}$ \\
\hline R-Square & 0.10 & 0.09 & 0.34 & 0.23 & 0.43 & 0.64 \\
\hline$N$ & 6,809 & 1,024 & 6,809 & 1,024 & 5,624 & 5,624 \\
\hline Industry Dummies? & No & No & Yes & Yes & Yes & Yes \\
\hline State/Region Dummies? & No & No & Yes & $N A^{\star \star}$ & No & Yes \\
\hline
\end{tabular}

* Results come from Subramanian and Deaton (1996) Table 2, p. 153.

${ }^{\star *}$ Note: Geographic detail is not available for the British sample

Male/Female $x-y$ is the share (proportion) of the household that is in that age-sex category.

Robust standard errors are listed under coefficient estimates in parentheses. 


\section{Table 6}

Comparison of 1888 Estimates of Caloric Elasticities With Estimates From Household Surveys Conducted in the Developing World Today

\begin{tabular}{ccc}
\multicolumn{3}{c}{ Expenditure Elasticity of Calories } \\
Nation & Method & Estimate \\
${ } }$ & OLS & 0.26 \\
Philippines & 2SLS & 0.32 \\
Philippines & OLS & 0.34 \\
Philippines & OLS & 0.43 \\
India & 2SLS & 0.44 \\
Indonesia-Rural & OLS & 0.51 \\
United States - 1888 & 2SLS/IV & 0.51 \\
United States - 1888 & OLS & 0.55 \\
Sri Lanka & OLS & 0.56 \\
Great Britain -1888 & 2SLS/IV & 0.62 \\
Great Britain - 1888 & OLS & 0.62
\end{tabular}

\section{Income Elasticity of Calories}

\begin{tabular}{|c|c|c|}
\hline Nation & Method & Estimate \\
\hline Mexico & OLS & 0.01 \\
\hline Philippines & OLS & 0.11 \\
\hline Brazil & OLS & 0.24 \\
\hline Philippines & $2 S L S$ & 0.28 \\
\hline Thailand & OLS & 0.33 \\
\hline
\end{tabular}

United States - $1888 \quad$ OLS $\quad 0.36$

Great Britain - $1888 \quad$ OLS $\quad 0.50$

Brazil 2SLS 0.53

Note: All non-1888 estimates are taken from Table 34.1 of Strauss and Thomas (1995, pp. 1894-1895) except those of Mexico, which come from Ruiz-Arranz, et. al. (2002)

For methodological consistency, only OLS and 2SLS estimates based upon caloric availability are reported in this table. For a discussion of the heterogeneity introduced by the estimation procedure and type of caloric unit see Strauss and Thomas (1995) and Deaton (1997). 
Table 7

Traditional and Elasticity (Engel Curve) Predicted GDP for Selected Countries

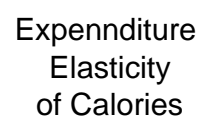

0.26

0.32

0.34

0.43

0.51

0.56

0.54

0.67

\author{
GDP Deflator \\ GDP per capita \\ estimate
}

\author{
Engel Curve \\ GDP per capita \\ estimate
}

30.71

304

9.89

36.88

286.86

7.77

36.88

281.14

7.62

36.88

255.43

6.93

30.71

232.57

7.57

Sri Lanka

United States - 1888

Great Britain - 1888

All GDP estimates in the table are in 1889 US dollars.

All non-1888 estimates of calorie elasticities are taken from Table 34.1 of Strauss and Thomas (1995, pp. 1894-1895)

Traditional GDP estimates for developing countries are for 1983 and are computed using the GDP deflator. The facor of convergence is the factor that the traditional GDP estimates must be multiplied by in order to produce the income estimates derived by the Engel curve. 
Figure 1

The Calorie Elasticity - Real GDP per Capita Line

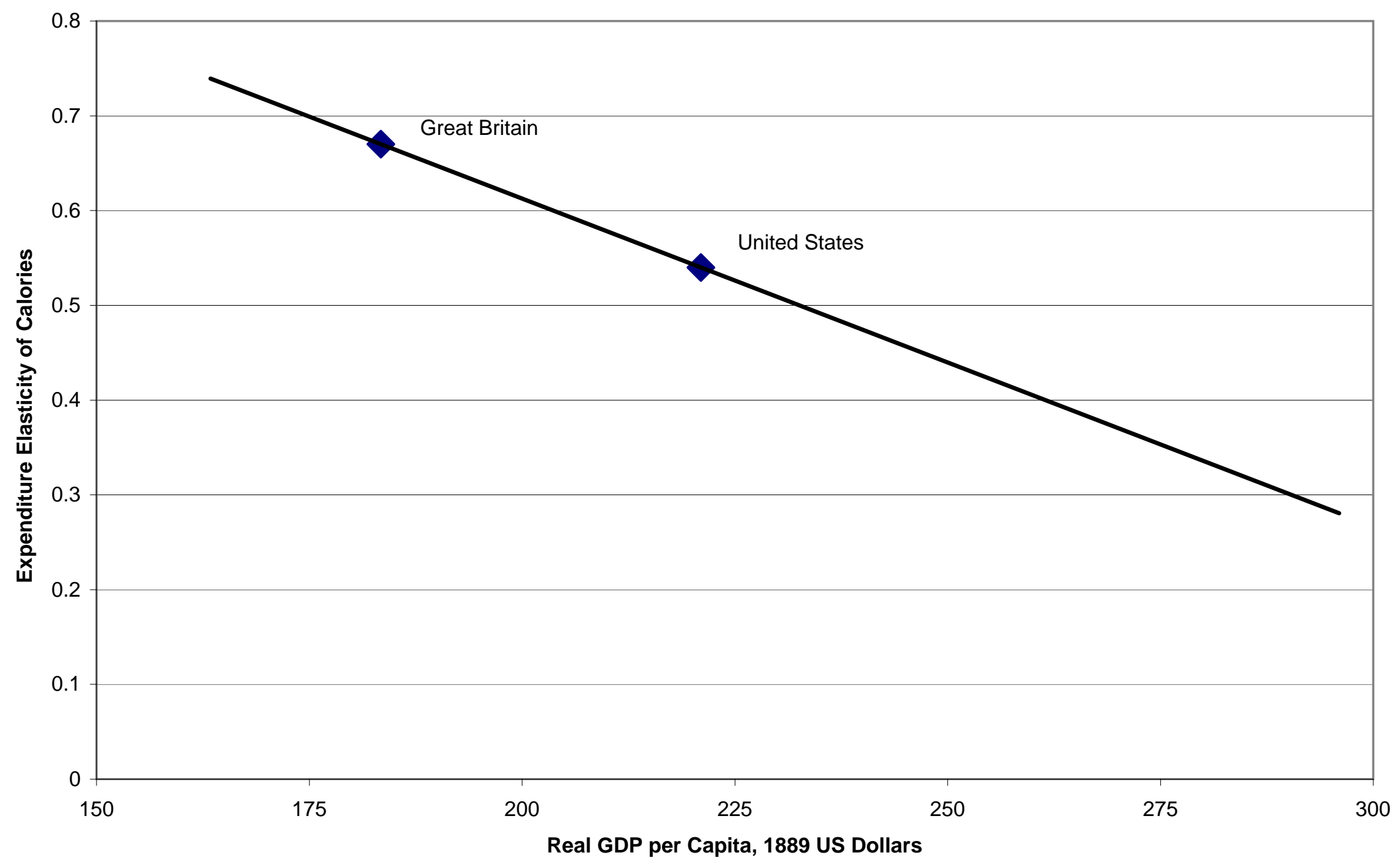




\section{Appendix}

The comments in the 1888CEX were analyzed systematically in order to investigate household production. Comments usually included a description of the dwelling (e.g. "home well kept” or "house filthy") and a mention of items owned by the household (sewing machines, poultry, organs, pianos, etc.). If a comment mentioned poultry, gardens, chickens, pigs, pork, cows, beef, fruit trees, or vegetables I noted that household as having home production. In looking at the comments, these were the only words and phrases that could be construed as implying home production of calories. As Table A1 shows, 27.15\% of American households and 9.38\% of British households in the survey had evidence of home production.

I then looked at the average log of per capita income and log of per capita expenditure for these groups. If the home production of calories objection is valid, then the income and expenditure distributions of home producing households should be markedly different from households with no evidence of home production. If the distributions are the same then home production is a level effect (in logs) and the elasticity estimate will not be influenced by the exclusion of home production. As Table A1 shows, the means of the log of per capita income and the log of per capita expenditure are very close for the two groups. In the British sample the means are approximately eight percentiles apart, and in the American sample they are approximately five percentiles apart. Even this difference, however, is an overstatement. In Table A2 I take account of households for which there are no comments and the differences between the two means falls to less than seven percentiles for the British sample, and less than four percentiles for the American sample.

The mean, however, is a relatively small part of the story. It is the distribution of home production that matters most. As the skewness results in Tables A1 and A2 confirm, American households with home production are just as skewed as households with no home production. In 
Britain households with home production are less skewed, but they account for a relatively small fraction of the total sample, and since more than a third of all households have no comment it is unclear how such evidence should be interpreted. Also, the kurtosis of the home producing households was less than that of the non-home producing households, and this suggest that the distribution of home production was more uniform than that of households with no home production. This once again suggests a level effect on the estimates of the elasticity. On balance, these results imply that the distribution of home production was not concentrated in lower income households.

While these results do not support the home production of calories objection, they do not deal a fatal blow to it. It would be cavalier to say that this analysis establishes that home production was not concentrated in low income households for two reasons. First, we do not know with any degree of certainty that a comment which does not mention home production implies that the household did not have home production. The true distribution of home production cannot be identified by these comments. Secondly, there is nothing in the remarks themselves that give us any clues about the amount of home production. While establishing that households with home production of calories were concentrated at lower incomes is necessary for the home production of calories objection, it is not sufficient for the objection to hold. One must show that wealthier households had less home production than poorer ones. This cannot be known or inferred from the comments. 


\section{Table A1}

Income, Expenditure and Remarks from 1888CEX

\begin{tabular}{|c|c|c|c|c|c|c|}
\hline \multicolumn{7}{|c|}{ United States Sample } \\
\hline Household Has & Total & $\begin{array}{l}\% \text { of } \\
\text { Total }\end{array}$ & $\begin{array}{l}\text { Average } \\
\text { Log of } \\
\text { Per Capita } \\
\text { Income }\end{array}$ & $\begin{array}{l}\text { Skewness } \\
\text { of Log of } \\
\text { Per capita } \\
\text { Income }\end{array}$ & $\begin{array}{c}\text { Average } \\
\text { Log of } \\
\text { Per Capita } \\
\text { Expenditure }\end{array}$ & $\begin{array}{l}\text { Skewness } \\
\text { of Log of } \\
\text { Per Capita } \\
\text { Expenditure }\end{array}$ \\
\hline Poultry and/or Garden* & 1,849 & $27.15 \%$ & $\begin{array}{c}9.4021 \\
(.51649)\end{array}$ & 0.2573 & $\begin{array}{c}9.3126 \\
(.44097)\end{array}$ & 0.3208 \\
\hline No Poultry and/or Garden & 4,960 & $72.85 \%$ & $\begin{array}{c}9.5125 \\
(.51604)\end{array}$ & 0.2581 & $\begin{array}{c}9.4424 \\
(.43848)\end{array}$ & 0.3136 \\
\hline Total & 6,809 & $100 \%$ & $\begin{array}{c}9.4821 \\
(.51848)\end{array}$ & 0.2533 & $\begin{array}{c}9.4066 \\
(.44296)\end{array}$ & 0.3033 \\
\hline$N=6,809$ & & & & & & \\
\hline \multicolumn{7}{|c|}{ Great Britain Sample } \\
\hline Household Has & Total & $\begin{array}{l}\% \text { of } \\
\text { Total }\end{array}$ & $\begin{array}{l}\text { Average } \\
\text { Log of } \\
\text { Per Capita } \\
\text { Income }\end{array}$ & $\begin{array}{l}\text { Skewness } \\
\text { of Log of } \\
\text { Per capita } \\
\text { Income }\end{array}$ & $\begin{array}{c}\text { Average } \\
\text { Log of } \\
\text { Per Capita } \\
\text { Expenditure }\end{array}$ & $\begin{array}{c}\text { Skewness } \\
\text { of Log of } \\
\text { Per Capita } \\
\text { Expenditure }\end{array}$ \\
\hline Poultry and/or Garden* & 96 & $9.38 \%$ & $\begin{array}{c}9.1823 \\
(.38533)\end{array}$ & 0.1050 & $\begin{array}{c}9.1204 \\
(.35741)\end{array}$ & 0.0413 \\
\hline No Poultry and/or Garden & 928 & $90.62 \%$ & $\begin{array}{c}9.2807 \\
(.42345)\end{array}$ & 0.2926 & $\begin{array}{c}9.2109 \\
(.37361)\end{array}$ & 0.2321 \\
\hline Total & 1,024 & $100 \%$ & $\begin{array}{c}9.2714 \\
(.42083)\end{array}$ & 0.28743 & $\begin{array}{c}9.2025 \\
(.37289)\end{array}$ & 0.2197 \\
\hline
\end{tabular}

Note: Only non-flower garden homes are included in the homes with gardens and/or polutry.

*Households with fruit trees, cows, and pigs are inclued in the Poulty and/or Garden Households. Standard errors are listed in parentheses under the sample means Positive values of skewness indicate the the distribution is skewed towards values greater than the mean. 


\section{Table A2}

Income, Expenditure, Remarks, and Missing Values from 1888CEX Remarks

\begin{tabular}{|c|c|c|c|c|c|c|}
\hline \multicolumn{7}{|c|}{ United States Sample } \\
\hline Household Has & Total & $\begin{array}{l}\% \text { of } \\
\text { Total }\end{array}$ & $\begin{array}{l}\text { Average } \\
\text { Log of } \\
\text { Per Capita } \\
\text { Income }\end{array}$ & $\begin{array}{l}\text { Skewness } \\
\text { of Log of } \\
\text { Per capita } \\
\text { Income }\end{array}$ & $\begin{array}{c}\text { Average } \\
\text { Log of } \\
\text { Per Capita } \\
\text { Expenditure }\end{array}$ & $\begin{array}{l}\text { Skewness } \\
\text { of Log of } \\
\text { Per Capita } \\
\text { Expenditure }\end{array}$ \\
\hline Poultry and/or Garden* & 1,849 & $27.15 \%$ & $\begin{array}{c}9.4021 \\
(.51649)\end{array}$ & 0.2573 & $\begin{array}{c}9.3126 \\
(.44097)\end{array}$ & 0.3208 \\
\hline No Poultry and/or Garden & 4,594 & $67.47 \%$ & $\begin{array}{c}9.5065 \\
(.51561)\end{array}$ & 0.2630 & $\begin{array}{c}9.4410 \\
(.44175)\end{array}$ & 0.3286 \\
\hline No Comments Made & 366 & $5.38 \%$ & $\begin{array}{c}9.5869 \\
(.51629)\end{array}$ & 0.2041 & $\begin{array}{c}9.4603 \\
(.39566)\end{array}$ & 0.0823 \\
\hline Total & 6,809 & $100 \%$ & $\begin{array}{c}9.4821 \\
(.51848)\end{array}$ & 0.2533 & $\begin{array}{c}9.4066 \\
(.44296)\end{array}$ & 0.3033 \\
\hline \multicolumn{7}{|l|}{$N=6,809$} \\
\hline \multicolumn{7}{|c|}{ Great Britain Sample } \\
\hline Household Has & Total & $\begin{array}{l}\% \text { of } \\
\text { Total }\end{array}$ & $\begin{array}{l}\text { Average } \\
\text { Log of } \\
\text { Per Capita } \\
\text { Income }\end{array}$ & $\begin{array}{l}\text { Skewness } \\
\text { of Log of } \\
\text { Per capita } \\
\text { Income }\end{array}$ & $\begin{array}{l}\text { Average } \\
\text { Log of } \\
\text { Per Capita } \\
\text { Expenditure }\end{array}$ & $\begin{array}{l}\text { Skewness } \\
\text { of Log of } \\
\text { Per Capita } \\
\text { Expenditure }\end{array}$ \\
\hline Poultry and/or Garden* & 96 & $9.38 \%$ & $\begin{array}{c}9.1823 \\
(.38533)\end{array}$ & 0.1050 & $\begin{array}{c}9.1204 \\
(.35741)\end{array}$ & 0.0413 \\
\hline No Poultry and/or Garden & 579 & $56.54 \%$ & $\begin{array}{c}9.2546 \\
(.40570)\end{array}$ & 0.3219 & $\begin{array}{c}9.1886 \\
(.36324)\end{array}$ & 0.2703 \\
\hline No Comments Made & 349 & $34.08 \%$ & $\begin{array}{c}9.3239 \\
(.44864)\end{array}$ & 0.2082 & $\begin{array}{c}9.2480 \\
(.38792)\end{array}$ & 0.1492 \\
\hline Total & 1,024 & $100 \%$ & $\begin{array}{c}9.2714 \\
(.42083)\end{array}$ & 0.28743 & $\begin{array}{c}9.2025 \\
(.37289)\end{array}$ & 0.21967 \\
\hline
\end{tabular}

$N=1,024$

Note: Only non-flower garden homes are included in the homes with gardens and/or polutry. *Households with fruit trees, cows, and pigs are inclued in the Poulty and/or Garden Households. Standard errors are listed in parentheses under the sample means.

Positive values of skewness indicate the the distribution is skewed towards values greater than the mean. 